\title{
Penerapan Algoritma K-Modes Clustering dengan Validasi Davies Bouldin Index pada Pengelompokkan Tingkat Minat Belanja Online di Provinsi Daerah Istimewa Yogyakarta
}

Alyeska Astri Az-zahra

Politeknik Statistika STIS, 211709536@stis.ac.id

Almira Fajriyati Marsaoly

Politeknik Statistika STIS, 211709529@stis.ac.id

Intan Putri Lestyani

Politeknik Statistika STIS,211709755@stis.ac.id

Roghibah Salsabila

Politeknik Statistika STIS, 211709986@stis.ac.id

Wa Ode Zuhayeni Madjida, S.ST, M.T.

Politeknik Statistika STIS, zuhayeni@stis.ac.id

\begin{abstract}
ABSTRAK, Kemajuan teknologi informasi dan komunikasi serta keberadaan internet yang semakin meluas di tengah masyarakat sehingga memunculkan kebiasaan-kebiasaan baru. Salah satunya adalah kebiasaan melakukan transaksi jual beli online. Kebiasaan baru tersebut menuntut para pemilik usaha untuk dapat menyesuaikan diri dengan perkembangan dunia transaksi saat ini. Penelitian ini bertujuan untuk mengetahui pengelompokkan minat belanja online yang dilakukan masyarakat Daerah Istimewa Yogyakarta berdasarkan faktor jenis kelamin, umur, dan platform yang diminati dengan penerapan Data Mining. Dengan adanya pengelompokkan ini diharapkan dapat memberikan pengetahuan bagi para pemilik online shop agar dapat mengetahui platform mana yang sering digunakan oleh masyarakat DIY dalam melakukan belanja online. Metode yang digunakan dalam mengelompokkan tingkat minat belanja online adalah $k$-Modes Clustering dengan nilai $k$ $=2,3,4, \ldots, 10$. Davies-Boulden Index (DBI) digunakan untuk menentukan jumlah klaster terbaik. Berdasarkan hasil analisis, diperoleh jumlah klaster terbaik yaitu $k=9$ dengan nilai DBI sebesar1,3427. Klaster 5 merupakan klaster terbaik yang anggotanya sangat minat belanja melalui Marketplace dan Media Sosial. Marketplace yang diminati adalah Shopee, Bukalapak, dan Tokopedia, sedangkan Media Sosial yang diminati adalah Instagram, Facebook, dan Media Chatting. Klaster ini didominasi oleh laki-laki umur muda (15-24 tahun).
\end{abstract}

Kata Kunci: belanja online; mengelompokkan; k-modes; data mining

\section{PENDAHULUAN}

Di era globalisasi saat ini, teknologi komunikasi dan informasi terus menerus berkembang menyesuaikan kebutuhan manumur dalam masyarakat. Berkembangnya teknologi komunikasi dan informasi yang semakin pesat termasuk internet memberikan dampak yang besar dalam berbagai aspek kehidupan. Adanya perkembangan teknologi menjadikan internet tidak hanya digunakan untuk berkomunikasi saja namun dapat juga digunakan untuk melakukan transaksi jual beli.

Dengan adanya teknologi digital, dapat mendorong perekonomian suatu negara ke arah ekonomi digital. Sebenarnya era ekonomi digital sudah berlangsung sejak tahun 1980-an, dengan menggunakan personal computer (PC) dan internet sebagai teknologi kunci yang digunakan untuk efisiensi bisnis. Penggunaan teknologi seperti PC dan internet ini pun menjadi awal dari perkembangan e-commerce. Seiring dengan perkembangan teknologi, era old digital economy akhirnya memasuki era new digital economy, ditandai dengan adanya mobile technology, akses internet yang tidak terbatas, serta kehadiran teknologi cloud yang digunakan dalam proses ekonomi digital [22].

Berdasarkan data Internet World Stats, pengguna internet di Indonesia mengalami peningkatan dari tahun ketahun dimana pada tahun 2018 Indonesia menempati peringkat ke-5 negara dengan jumlah pengguna internet tertinggi di dunia yaitu sekitar 143 juta orang. Dengan perkembangan pengguna internet yang semakin pesat dapat menjadi sebuah potensi bisnis yang sangat menjanjikan. Jumlah pengguna internet yang terus meningkat dapat menjadi pasar yang potensial untuk dimasuki 
para pebisnis dan aktualisasi belanja yang terjadi sangat cepat, nyaman, dan dapat dilakukan kapan saja dan dimana saja.

Perkembangan jumlah pengguna internet dapat mendorong terjadinya suatu potensi besar terciptanya usaha melalui media internet seperti online shop yang terdapat di berbagai platform, mulai dari media sosial hingga aplikasi chat. Dengan kemudahan akses yang ditawarkan oleh adanya usaha melalui internet, membuat masyarakat mulai merubah perilaku dalam belanja barang kebutuhan menjadi belanja secara online melalui handphone atau computer dengan memanfaatkan fasilitas internet.

Provinsi di Indonesia yang berpotensi untuk pengembangan usaha melalui internet adalah Daerah Istimewa Yogyakarta (DIY). Menurut data BPS, pada tahun 2018 DIY berada di posisi kedua terbesar di Indonesia setelah DKI Jakarta, dimana proporsi individu pengguna internet di DIY sebesar 55,45 persen. Hal ini juga diikuti dengn banyaknya jumlah usaha yang memanfaatkan internet dalam keperluan usahanya. Data statistik e-commerce BPS tahun 2019 menunjukkan bahwa persentase usaha yang melakukan e-commerce di DIY sebesar 27,88 persen, DIY memiliki persentase tertinggi seIndonesia.

Berdasarkan hal tersebut peneliti ingin melakukan pengelompokkan minat belanja online dilakukan berdasarkan faktor umur, jenis kelamin dan platform yang diminati dengan penerapan Data Mining. Dengan adanya pengelompokkan diharapkan dapat memberikan pengetahuan bagi para pemilik online shop agar dapat mengetahui platform mana yang sering digunakan oleh masyarakat DIY dalam melakukan belanja online. Sehingga hal ini dapat bermanfaat dalam pengambilan keputusan berjualan online melalui platform apa, mengingat DIY merupakan provinsi yang berpotensi untuk pengembangan usaha melalui internet.

Metode statistika yang digunakan untuk pengelompokkan minat belanja online adalah analisis klaster karena analisis klaster dapat mengelompokkan objek ke dalam kelompok yang relatif homogen [7]. Metode analisis klaster yang sering digunakan adalah analisis klaster $k$ Means, namun algoritma $k$-Means hanya bekerja terbatas pada dataset yang atributnya bertipe numerik. Sedangkan untuk data bertipe kategorik menggunakan algoritma klastering $k$-Modes merupakan pengembangan dari algoritm kMeans [10]. Jumlah klaster dapat ditentukan sebanyak dua, tiga, dan seterusnya dimana setiap klaster memiliki karakteristik yang sama. jumlah klaster optimal dapat diperiksa menggunakan Davies-Bouldin Index (DBI). Jumlah klaster yang dipilih adalah jumlah klaster yang memiliki nilai DBI terkecil [15].

\section{TINJAUAN PUSTAKA}

\section{E-Commerce}

E-Commerce adalah proses membeli, menjual, atau memperdagangkan data, barang, atau jasa melalui internet [21]. Media $e$ commerce melibatkan penggunaan website, internet, dan aplikasi maupun browser pada perangkat seluler untuk bertransaksi bisnis. Pada awal berkembangnya e-commerce, media digital yang tersedia hanya web browser, namun sekarang yang lebih banyak digunakan oleh orang-orang adalah aplikasi pada perangkat seluler [12].

\section{Digital Economy}

Pemanfaatan teknologi informasi dan komunikasi terjadi pada hampir semua lini kehidupan termasuk bidang ekonomi. Sektor ekonomi merupakan pionir dalam pemanfaatan internet setelah proyek ARPANET (Advance Research Projexts Agency) dalam bidng militer. Ekonomi digital pertama kali dikemukakan oleh Tapscott. Tapscott mengungkapkan bahwa internet dan web memunculkan bentuk ekonomi baru berdasarkan jaringan human intelligence [20]. Menurut OECD (Organization for Economic Co-operation and Development), ekonomi digital adalah pasar yang dibentuk oleh teknologi digital yang memfasilitasi perdagangan barang maupun jasa melalui $e$ commerce.

\section{Analisis Klaster}

Analisis

pengelompokan

klaster

merupakan

kelompok yang lebih kecil, dimana setiap 
kelompok berisi objek yang memiliki kemiripan satu sama lain [19]. Analisis klaster adalah kumpulan dari beberapa teknik pengolahan data multivariat yang memiliki tujuan utama mengelompokkan objek-objek berdasarkan karakteristik yang dimilikinya [7]. Klaster yang terbentuk harus menunjukkan homogenitas internal yang tinggi dalam satu klaster dan heterogenitas yang tinggi antar klaster.

Farley dan Raftery membagi metode clustering ke dalam dua kelompok utama, yaitu metode hirarki dan metode partisi [5]. Algoritma clustering hirarki digunakan untuk mengelompokkan objek secara terstruktur berdasarkan kemiripan sifatnya dan klaster yang diinginkan belum diketahui banyaknya [13]. Metode hirarki dibagi menjadi dua yaitu, algoritma agglomerative (seperti single-linkage, complete-linkage, average linkage, metode centroid dan metode ward) dan algoritma divisive.

Sementara itu, Algoritma clustering non hirarki/partisi digunakan untuk pengelompokan objek dimana banyaknya klaster yang akan dibentuk dapat ditentukan terlebih dahulu sebagai bagian dari prosedur pengelompokan [11]. Metode partisi merelokasi secara instan data-data yang ada dengan memindahkan data tersebut dari satu cluster ke cluster yang lain, dan memulai partisi dari awal. Beberapa tipe metode partisi adalah: (i) Error Minimization Algorithms (K-Means Algorithm, K-Modes Algorithm) dan (ii) Graph-Theoritic Clustering (Minimal Spanning Tree-MST) [17].

\section{Uji Multikolinieritas}

Pada analisis klaster harus memenuhi asumsi non-multikolinearitas [7]. Multikolinieritas mengindikasikan adanya hubungan linier sempurna atau pasti antara beberapa atau semua variabel [6]. Terkadang variabel independen saling terhubung erat dan sulit untuk membedakan pengaruh masingmasing variabel independen dengan variabel dependen. Keadaan tersebut dinamakan collinear atau pada variabel tersebut terjadi masalah kolinieritas. Satu set variabel dikatakan multikolinier jika terdapat satu atau lebih hubungan linier antara beberapa variabel.

Uji Multikolinieritas digunakan untuk menguji apakah terdapat korelasi antar variabelvariabel bebas. Salah satu cara untuk mendeteksi adanya multikolinieritas adalah dengan menghitung nilai Varians Inflation Factor (VIF) [6]. Misalkan terdapat regresi linier :

$$
Y=\boldsymbol{X} \boldsymbol{\beta}+\varepsilon
$$

atau

$$
Y=\beta_{0}+\beta_{1} X_{1}+\cdots+\beta_{k} X_{k}+\varepsilon_{k}
$$

$\mathrm{X}$ merupakan matriks full-rank $n \times p$ dan $\mathcal{L}(\varepsilon)=$ $N\left(0, \sigma^{2} I_{n}\right) . \quad V I F_{j}$ dievaluasi dalam langkahlangkah berikut [3]:

1. Jalankan regresi tambahan OLS dari $\mathrm{Xj}$ sebagai fungsi dari semua variabel penjelasan lainnya:

$$
\begin{gathered}
X_{j}=\alpha_{0}+\alpha_{1} X_{1}+\cdots+\alpha_{j-1} X_{j-1}+ \\
\alpha_{j+1} X_{j+1} \ldots+\alpha_{k} X_{k}+e_{i} \\
\mathrm{j}=1,2, \ldots, \mathrm{k}
\end{gathered}
$$

2. Mencari nilai VIF untuk setiap j dengan rumus

$$
V I F_{j}=\frac{1}{1-R_{j}^{2}}
$$

dimana $R_{j}^{2}$ adalah koefisien determinasi regresi pada langkah (1)

3. Jika nilai VIF di bawah 10 , maka tidak terjadi gejala multikolinieritas [6].

VIF mengukur akibat dari penambahan 1 variabel eksplanatori yang tidak ortogonal pada model regresi linier, dan dapat dihitung sebagai rasio dari determinan [14].

Namun, VIF tidak sepenuhnya dapat digunakan pada model, yang mana mencakup serangkaian regresor, yaitu indikator/dummy untuk variabel kategori yang sama ataupun regresi polinomial. Hal ini terjadi karena korelasi antara variabel-variabel tersebut diinduksi oleh struktur model. Masalahnya adalah bahwa nilai VIF dipengaruhi oleh garis dasar variabel kategoris. Untuk memastikan tidak ada variabel yang memiliki nilai VIF di atas nilai batas yang dapat diterima, perlu untuk mengulangi analisis ini untuk setiap tingkat variabel kategorik. Misal pada suatu variabel umur terdapat 4 kategori yaitu kelompok umur anak-anak, remaja, dewasa, dan lansia, serta kelompok umur anak- 
anak sebagai kelompok acuan, maka terdapat tiga dummy variabel untuk kategori umur sehingga kita perlu menghitung VIF dari dummy variabel tersebut (kelompok umur remaja, dewasa, dan lansia). Sehingga untuk mengetahui apakah variabel umur tidak terjadi multikolinearitas perlu dilakukan penghitungan sebanyak banyaknya dummy variabel. Hal ini menjadi lebih rumit jika kita memiliki lebih dari satu variabel kategorik. Maka untuk mengatasi hal tersebut, dapat menggunakan Generalized VIF atau GVIF [4]. Dalam menghitung GVIF kita mulai dengan memisahkan variabel dummy untuk variabel kategori umur dalam matriks terpisah $X_{i}$ dan variabel penjelasan yang tersisa (tidak termasuk konstanta) di $X_{[-i]}$.

GVIF adalah faktor inflasi variasi umum, yang digunakan sebagai pengganti VIF standar karena VIF standar tidak dapat diterapkan pada variabel dengan Df $>1$ (misalnya, variabel kategorik dengan beberapa kategori). GVIF dihitung untuk set regresor terkait, seperti untuk serangkaian regresor indicator/dummy untuk beberapa jenis variabel kategorik, atau untuk variabel polynomial. Singkatnya, GVIF adalah VIF yang dikoreksi dengan jumlah derajat kebebasan variabel independen, artinya untuk variabel kontinu, VIF dan GVIF adalah sama nilainya. Sedangkan untuk variabel kategorik, kita akan mendapatkan satu nilai GVIF untuk setiap jenis kategori terpisah (misalnya pada variabel umur yang terdiri atas 4 kategori hanya akan menghasilkan satu nilai GVIF). Jadi, variabel yang membutuhkan lebih dari 1 koefisien dan dengan demikian memiliki derajat kebebasan lebih dari 1 biasanya dievaluasi menggunakan GVIF.

Misal model regresi sebagai berikut :

Atau

$$
Y_{(N \times 1)}=X_{(N \times(l+1))} \beta_{((l+1) \times 1)}+\varepsilon_{(N \times 1)}
$$

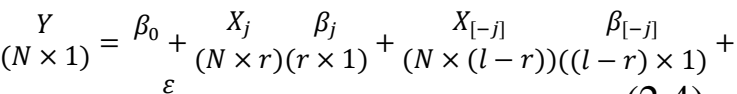

$$
\begin{aligned}
& (N \times 1)
\end{aligned}
$$

Keterangan :

$X_{j}=$ Variabel independen yang akan dicari GVIFnya dan suku polinomialnya

$X_{[-j]}=$ Seluruh variabel pada matriks $\mathrm{X}$ selain variabel pada $\mathrm{X}_{\mathrm{j}}$, tidak termasuk konstanta $\mathrm{N}$ = Jumlah sampel
$1=$ Jumlah seluruh variabel independen

$\mathrm{r}=$ Jumlah variabel indikator/dummy pada variabel kategorik tertentu

Maka GVIF didefinisikan sebagai berikut:

Dimana :

$$
G V I F_{j}=\frac{\operatorname{det}\left(R_{X_{j}}\right) \operatorname{det}\left(R_{X_{[-j]}}\right)}{\operatorname{det}(R)}
$$

$R_{X_{j}} \quad=$ Matriks korelasi untuk $X_{j}$

$R_{X_{[-j]}}=$ Matriks korelasi untuk $X_{[-j]}$

$\mathrm{R}=$ Matriks korelasi untuk seluruh variabel pada matriks $\mathrm{X}$, kecuali konstanta

Untuk membuat GVIF sebanding di seluruh dimensi dan mengurangi GVIF ke ukuran linier Fox dan Monette juga menyarankan menggunakan $G V I F^{\frac{1}{2 \times d f}}$ [4]. Dimana df adalah jumlah koefisien dalam subset variabel (misalnya, untuk variabel umur dengan kategori umur anak-anak sebagai variabel acuan, df =3). Kemudian kita dapat mendeteksi multikolinearitas dengan aturan yang sama dengan VIF yaitu nilai kurang dari 10 menunjukkan tidak adanya multikolinearitas.

\section{Algoritma K-Modes Clustering}

Proses klasterisasi pada data kategorik (nominal atau ordinal) yang tidak dapat menggunakan algoritma $k$-means clustering membuat tercetusnya suatu algoritma baru pada tahun 1997 yang disebut dengan $k$-modes clustering. Algoritma data mining ini merupakan pengembangan dari algoritma k-means clustering dan digunakan untuk mengelompokkan data kategorik dengan menghitung fungsi jarak mismatching [23]. Hal ini yang membedakan penggunaan algoritma $k$ means dengan $k$-modes. Penggunaan $k$-means clustering hanya terbatas pada jenis data numerik (interval/rasio) yang pengklasterisasian datanya dilakukan dengan menghitung fungsi jarak euclidean dan rata-rata suatu data dengan data yang lain serta tidak dapat mengklasterisasikan data kategorik. Sementara itu, $k$-modes clustering dapat melakukan klasterisasi pada data kategorik dengan cara menghitung ukuran ketidakmiripan antara dua data [23].

Tahapan clustering menggunakan algoritma $k$-modes adalah sebagai berikut [2] : 
1. Menghitung jumlah klaster (k) yang akan dibentuk dari $r$ data. Banyaknya klaster harus lebih sedikit dari banyaknya data $(\mathrm{k}<\mathrm{r})$.

2. Memilih $\mathrm{k}$ modus awal dari data secara acak sebagai pusat klaster (centroid).

Jumlah centroid yang dibuat harus sama dengan jumlah klaster yang akan dibentuk. Misalnya, jika ingin membentuk tiga klaster, maka centroid juga berjumlah tiga.

3. Menghitung jarak setiap data (objek) terhadap semua centroid.

Jarak dihitung dengan menggunakan ukuran ketidakmiripan sederhana (simple matching dissimilarity) Asumsikan $A_{1}$ dan $A_{2}$ adalah dua data yang memiliki $n$ variabel kategorik. Ukuran ketidakmiripan antara $A_{1}$ dan $A_{2}$ dapat didefinisikan sebagai total ketidakcocokan dari variabel-variabel kategorik yang sesuai dari kedua data. Semakin kecil nilai ketidakcocokan, semakin mirip kedua data tersebut [10]. Persamaan ukuran ketidakmiripan sederhana dirumuskan sebagai berikut. dengan

$$
d\left(A_{1}, A_{2}\right)=\sum_{j=1}^{n} \delta\left(x_{1 j}, x_{2 j}\right)
$$

$$
\delta\left(x_{1 j}, x_{2 j}\right)= \begin{cases}0 & x_{1 j}=x_{2 j} \\ 1 & x_{1 j} \neq x_{2 j}\end{cases}
$$

$x_{1 j}$ adalah nilai dari variabel ke-j pada objek $A_{1}$ dan $x_{2 j}$ adalah nilai dari variabel ke-j pada objek $A_{2}$.

4. Mengalokasikan objek berdasarkan jarak terdekat ke centroid dengan rumus jarak terdekat. Nilai ukuran ketidakmiripan sederhana ini dapat menunjukkan klaster mana yang paling dekat dengan data.

5. Jika semua data telah dialokasikan ke dalam klaster terdekat, selanjutnya memperbarui centroid masing-masing klaster berdasarkan modus dari setiap variabel anggota klaster yang terbentuk.

6. Menghitung ulang jarak setiap data terhadap semua centrroid baru dengan menggunakan ukuran ketidakmiripan sederhana seperti langkah (3). Jika pada penghitungan ulang jarak, data lebih mendekati klaster lain daripada klaster saat ini, maka data dialokasikan ulang ke klaster lain yang lebih dekat tersebut.

7. Mengulangi langkah (5) dan (6) hingga tidak ada data yang berpindah klaster.

\section{Modus Klaster}

Pada algoritma $k$-modes clustering, pusat klaster (centroid) diwakili oleh vektor modus dari variabel kategorik. Dalam statistika, modus dari sekumpulan nilai yaitu nilai yang paling sering muncul. Jika sekumpulan data memiliki $n$ variabel kategorik. Vektor modus $V$ terdiri dari $n$ nilai kategorik $\left(v_{1}, v_{2}, \ldots, v_{n}\right)$ yang masingmasing merupakan modus dari sebuah variabel. Vektor modus dari sebuah klaster meminimalkan jumlah jarak antar setiap data di dalam karakter dengan pusat klaster [9].

\section{Indeks Davies-Bouldin}

Davies-Bouldin Index (DBI) adalah suatu ukuran yang digunakan unuk menentukan jumlah klaster yang terbaik setelah proses pengklasteran selesai [15]. Pendekatan DBI ini bertujuan untuk memaksimalkan jarak antara klaster yang satu dengan klaster yang lain dan mencoba meminimalkan jarak antar objek dalam suatu klaster [8]. Semakin kecil nilai DBI yang diperoleh (non-negatif $\geq 0$ ) maka semakin baik klaster yang diperoleh dari pengelompokkan $k$ modes clustering yang digunakan [18]. Formula Indeks Davies-Bouldin adalah sebagai berikut.

dengan

$$
D B I=\frac{1}{k} \times \sum_{a=1}^{k} R_{a}
$$

$$
R_{a}=\max _{a \neq b} R_{a b} \text { dan } R_{a b}=\frac{s_{a}+s_{b}}{d\left(V_{a}, V_{b}\right)}
$$

Keterangan :

DBI = Indeks Davies-Bouldin

$\mathrm{k} \quad=$ Jumlah klaster

$R_{a b}=$ Ukuran kemiripan antara klaster ke-a dan klaster ke-b

$s_{a} \quad=$ Ukuran dispersi klaster ke-a

$s_{b} \quad=$ Ukuran dispersi klaster ke-b

a $\quad=1,2, \ldots, \mathrm{k}$

$\mathrm{b} \quad=1,2, \ldots, \mathrm{k}$ 


$$
s_{a}=\left[\frac{1}{n_{a}} \sum_{T_{i} \in c_{a}, i=1}^{n_{a}}\left(d\left(T_{i}, V_{a}\right)\right)^{2}\right]^{\frac{1}{2}}
$$

Keterangan :

$n_{a} \quad=$ Banyaknya anggota klaster ke-a

$c_{a} \quad=$ Klaster ke-a

$T_{i} \quad=$ Anggota ke-i pada klaster ke-a

$V_{a} \quad=$ Centroid klaster ke-a

$d\left(T_{i}, V_{a}\right)=$ Jarak dari anggota ke-i pada klaster

ke-a $\left(T_{i}\right)$ dengan centroid klaster ke-a $\left(V_{a}\right)$

Nilai $d\left(T_{i}, V_{a}\right)$ dihitung menggunakan ukuran ketidaksamaan percocokan sederhana yang dapat dijabarkan sebagai berikut :

$$
d\left(T_{i}, V_{a}\right)=\sum_{j=1}^{n} \delta\left(x_{i j}, v_{a j}\right)
$$

dengan

Dimana

$$
\delta\left(x_{i j}, v_{a j}\right)= \begin{cases}0 & x_{i j}=v_{a j} \\ 1 & x_{i j} \neq v_{a j}\end{cases}
$$

$x_{i j} \quad=$ Nilai dari variabel ke-j pada $\mathrm{T}$ ke-i

$v_{a j} \quad=$ Nilai ke-j pada centroid klaster ke-a

$\mathrm{N} \quad=$ Jumlah variabel

Formula untuk mencari nilai varians klaster ke-b juga sama dengan formula untuk mencari nilai varians klaster ke-a di atas.

Ukuran ketidakmiripan percocokan sederhana dapat juga digunakan untuk menghitung jarak centroid klaster ke-a $\left(V_{a}\right)$ ke centroid klaster ke-b $\left(V_{b}\right)$ sebagai berikut :

$$
d\left(V_{a}, V_{b}\right)=\sum_{j=1}^{n} \delta\left(v_{a j}, v_{b j}\right)
$$

dengan

$$
\delta\left(v_{a j}, v_{b j}\right)= \begin{cases}0 & v_{a j}=v_{b j} \\ 1 & v_{a j} \neq v_{b j}\end{cases}
$$

dimana $v_{b j}$ adalah nilai ke-j pada centroid klaster ke-b.

\section{METODOLOGI}

Penelitian ini menggunakan data sekunder yang diperoleh dari raw data hasil survei Praktik Kerja Lapangan (PKL) Politeknik Statistika STIS Tahun Akademik 2019/2020. Salah satu tujuan dari survei tersebut adalah untuk mengetahui karakteristik pelaku ekonomi digital di Daerah Istimewa Yogyakarta. Pengambilan data pada survei menerapkan probability sampling dengan desain Stratified Two Stage Sampling. Variabel yang digunakan pada penelitian ini adalah jenis kelamin, umur dan jenis platform yang digunakan dalam melakukan pembelian barang secara online. Jenis platform yang dicakup yaitu Marketplace (Shopee, Bukalapak, Tokopedia, Lazada, lainnya) dan Media Sosial (Instagram, Facebook, Media Chat, Twitter).

Tabel 3.1 Variabel Penelitian

\begin{tabular}{cc}
\hline Variabel & Nama Variabel \\
\hline $\mathrm{X}_{1}$ & Jenis Kelamin \\
$\mathrm{X}_{2}$ & Umur \\
$\mathrm{X}_{3}$ & Shopee \\
$\mathrm{X}_{4}$ & Bukalapak \\
$\mathrm{X}_{5}$ & Tokopedia \\
$\mathrm{X}_{6}$ & Lazada \\
$\mathrm{X}_{7}$ & Marketplace Lainnya \\
$\mathrm{X}_{8}$ & Instagram \\
$\mathrm{X}_{9}$ & Facebook \\
$\mathrm{X}_{10}$ & Media Chat \\
$\mathrm{X}_{11}$ & Twitter \\
\hline
\end{tabular}

Pada variabel jenis kelamin terdapat dua kategori yaitu Laki-laki $=1$ dan Perempuan $=2$; variabel umur terdiri atas tiga kategori yaitu Muda $=1$, Dewasa $=2$, dan Tua $=3$; variabel shopee, bukalapak, sampai twitter memiliki dua kategori yaitu $\mathrm{Ya}=1$ dan Tidak $=0$.

Metode analisis yang dilakukan berupa analisis secara deskriptif maupun inferensia. Analisis deskriptif menggambarkan karakteristik pelaku ekonomi digital untuk masing-masing variabel menggunakan diagram lingkaran. Selanjutnya, secara inferensia menggunakan metode $k$-modes clustering untuk mengelompokkan minat belanja online berdasarkan variabel yang digunakan. Data yang diambil sebanyak 2415 record dilakukan preprocessing terlebih dahulu untuk mengatasi permasalahan yang dapat mengganggu proses pengolahan data. Setelah itu, dilakukan uji asumsi non-multikolinearitas untuk membuktikan bahwa tidak terdapat kolinearitas antar variabel. 
Kemudian, langkah-langkah yang dilakukan untuk analisis klaster pada penelitian ini adalah sebagai berikut :

1. Memasukkan data variabel

2. Menentukkan nilai $k=2,3, \ldots 10$

3. Menentukan centroid (pusat klaster) secara acak dari masing-masing klaster

4. Menghitung jarak tiap objek terhadap centroid menggunakan ukuran ketidaksamaan sederhana.

5. Mengelompokkan objek berdasarkan jarak terdekat ke centroid.

6. Menentukan modus dari setiap variabel sebagai centroid klaster.

7. Menghitung ulang jarak tiap objek terhadap centroid baru menggunakan ukuran ketidaksamaan sederhana.

8. Mengelompokkan objek berdasarkan jarak terdekat ke centroid.

9. Apabila ada objek yang berpindah klaster, maka ulangi langkah ke enam sampai delapan hingga tidak ada objek yang berpindah klaster.

10. Memilih k terbaik menggunakan Davies Bouldin Index.

11. Membuat profiling dari masing-masing klaster.

Gambar 3.1 merupakan diagram alir algoritma $k$-modes clustering [20].

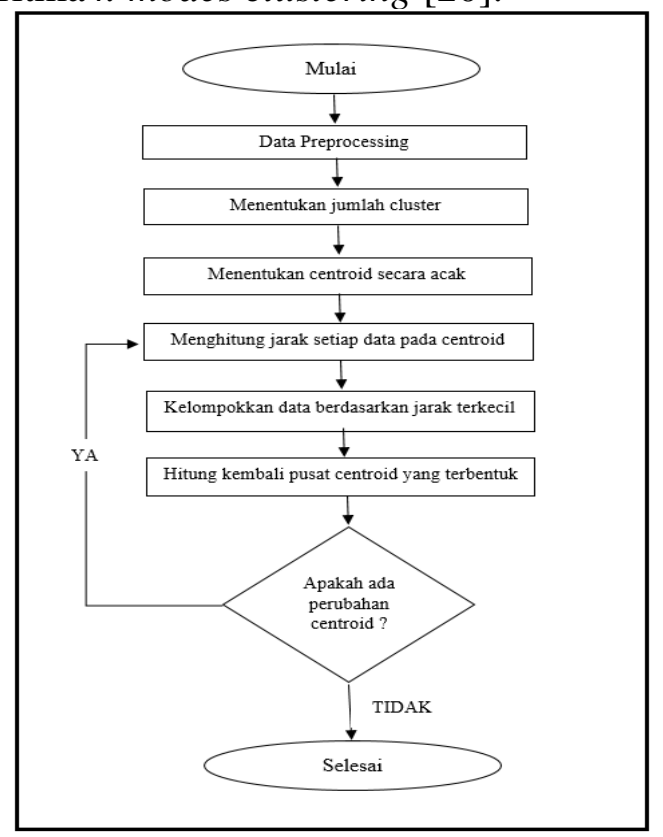

Gambar 3.1. Flowchart Proses Klastering

\section{PEMBAHASAN}

\section{Analisis Deskriptif}

Persentase Penduduk Daerah Istimewa Yogyakarta yang Melakukan Belanja Online Berdasarkan Jenis Kelamin

Berdasarkan gambar 4.1 diketahui bahwa persentase penduduk perempuan yang melakukan kegiatan belanja online adalah sebesar 54 persen. Sedangkan untuk penduduk laki-laki adalah sebesar 46 persen. Hal tersebut menunjukkan bahwa pada Daerah Istimewa Yogyakarta kecenderungan belanja online dilakukan oleh penduduk perempuan maupun laki-laki.

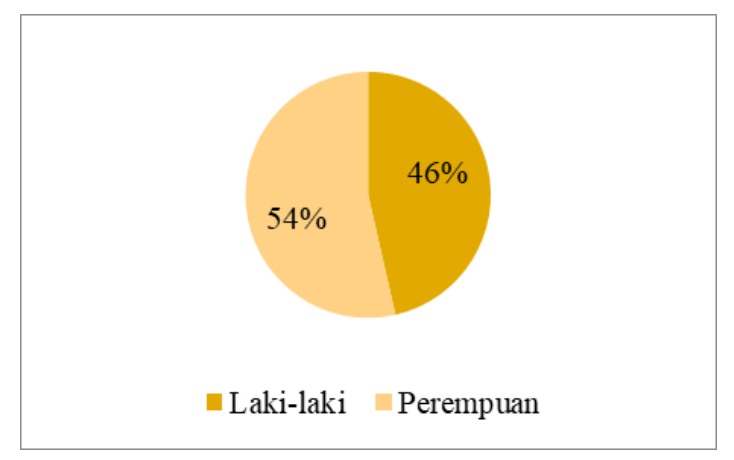

Gambar 4.1. Persentase Penduduk yang melakukan Belanja Online Berdasarkan Jenis Kelamin

\section{Persentase Penduduk Daerah Istimewa Yogyakarta yang Melakukan Belanja Online Berdasarkan Umur}

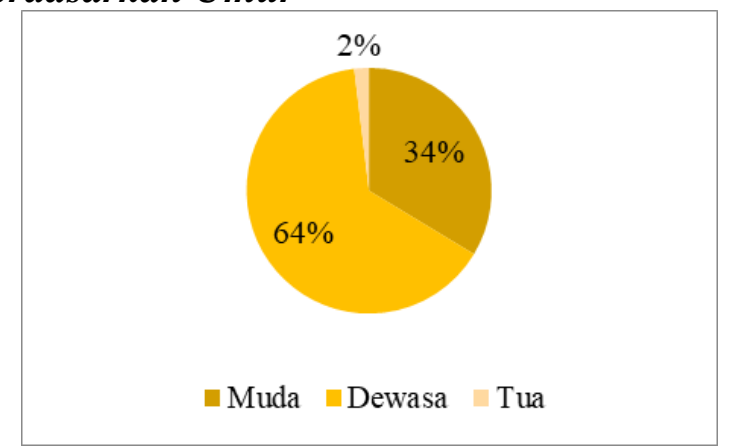

Gambar 4.2 Persentase Penduduk yang melakukan Belanja Online Berdasarkan Umur

Berdasarkan gambar 4.2 penduduk pada Daerah Istimewa Yogyakarta 64 persen yang melakukan belanja online merupakan umur 
dewasa yaitu 25-59 tahun. Untuk umur muda yang melakukan kegiatan belanja online adalah sebesar 34 persen dan untuk 2 persen sisanya adalah umur tua. Hal ini menunjukkan bahwa mayoritas penduduk yang melakukan kegiatan belanja online adalah umur dewasa yang notabenenya sudah memiliki pekerjaan dan juga penghasilan. Umur tersebut merupakan umur produktif bekerja.

Persentase Penduduk Daerah Istimewa Yogyakarta yang Melakukan Belanja Online Berdasarkan Platform

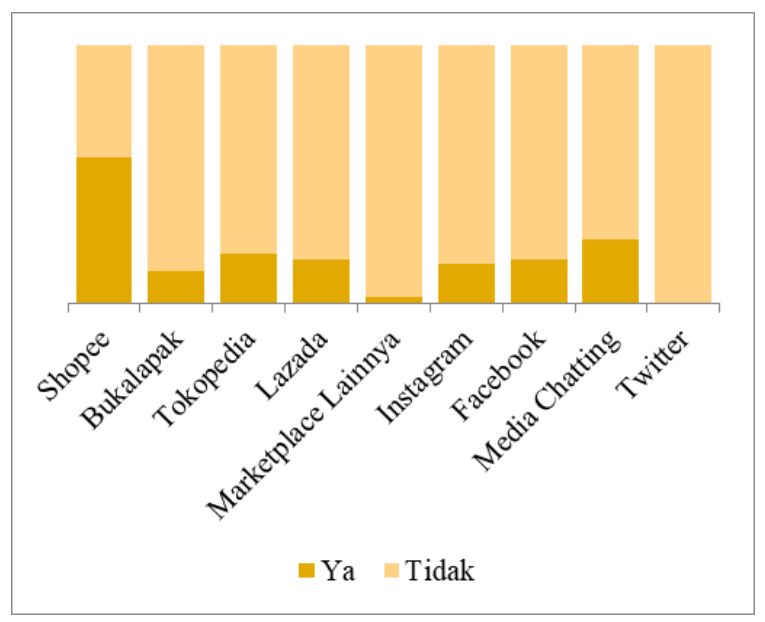

Gambar 4.3 Persentase Penduduk yang melakukan Belanja Online Berdasarkan Platform

Jika dilihat berdasarkan platform yang digunakan, mayoritas penduduk di Daerah Istimewa Yogyakarta menggunakan aplikasi Shopee sebagai media untuk belanja online, yaitu sebesar 56,36 persen. Sedangkan platform yang paling sedikit digunakan untuk belanja online adalah Twitter.

\section{ANALISIS INFERENSIA}

\section{Uji Multikolinearitas}

Dalam melakukan analisis klaster, terdapat beberapa asumsi yang harus dipenuhi yaitu sampel representatif (mewakili populasi) dan non-multikolinearitas (tidak ada korelasi antar variabel). Pengujian untuk asumsi nonmultikolinearitas dapat diketahui dari nilai Generalized Variance Inflation Factor (GVIF), jika nilai GVIF < 10 maka asumsi nonmultikolinearitas terpenuhi.
Tabel 4.1 Nilai GVIF Masing-Masing Variabel

\begin{tabular}{cc}
\hline Variabel & GVIF $\frac{\mathbf{1}}{\mathbf{2 \times d f}}$ \\
\hline Jenis Kelamin & 1,0584 \\
Umur & 1,0102 \\
Shopee & 1,0985 \\
Bukalapak & 1,0636 \\
Tokopedia & 1,0542 \\
Lazada & 1,0346 \\
Marketplace Lainnya & 1,0107 \\
Instagram & 1,0964 \\
Facebook & 1,1046 \\
Media Chatting & 1,1534 \\
Twitter & 1,0092 \\
\hline
\end{tabular}

Berdasarkan Tabel 2 dapat diketahui bahwa nilai GVIF masing-masing variabel bernilai kurang dari 10 sehingga dapat disimpulkan bahwa asumsi nonmultikolinearitas terpenuhi.

\section{Hasil Pengklasteran}

Setelah dilakukan klasterisasi terhadap daa, didapatkan hasil yang ditunjukkan pada tabel 4.2 untuk centroid atau modus dari masingmasing kluster dan masing-masing $\mathrm{k}$.

Tabel 4.2 Hasil pengklasteran $\mathrm{k}=2,3, \ldots, 10$

\begin{tabular}{cccc}
\hline $\mathbf{k}$ & Klaster & $\begin{array}{c}\text { Jumlah } \\
\text { Anggota } \\
\left(\mathbf{n}_{\mathbf{a}}\right)\end{array}$ & Centroid $\left(\mathbf{V}_{\mathbf{a}}\right)$ \\
\hline \multirow{2}{*}{2} & 1 & 1595 & $1,2,0,0,0,0,0,0,0,0,0$ \\
& 2 & 820 & $2,2,1,0,0,0,0,0,0,0,0$ \\
3 & 1 & 1361 & $1,2,0,0,0,0,0,0,0,0,0$ \\
& 2 & 787 & $2,2,1,0,0,0,0,0,0,0,0$ \\
& 3 & 267 & $1,1,0,0,0,0,0,1,0,1,0$ \\
& 1 & 667 & $2,2,0,0,0,0,0,0,0,1,0$ \\
4 & 2 & 1146 & $2,2,1,0,0,0,0,0,0,0,0$ \\
& 3 & 203 & $1,1,0,0,0,0,0,1,0,1,0$ \\
& 4 & 399 & $1,2,0,0,0,0,0,0,0,0,0$ \\
& 1 & 663 & $2,2,0,0,0,0,0,0,0,1,0$ \\
5 & 2 & 1134 & $2,2,1,0,0,0,0,0,0,0,0$ \\
& 3 & 80 & $1,1,0,0,0,0,0,1,0,1,0$ \\
& 4 & 399 & $1,2,0,0,0,0,0,0,0,0,0$ \\
& 5 & 119 & $1,1,1,1,1,0,0,1,1,10$ \\
& 1 & 624 & $2,2,0,0,0,0,0,0,0,1,0$ \\
& 2 & 1134 & $2,2,1,0,0,0,0,0,0,0,0$ \\
6 & 3 & 80 & $2,1,0,0,0,0,0,1,0,1,0$ \\
& 4 & 399 & $1,2,0,0,0,0,0,0,0,0,0$ \\
& 5 & 104 & $1,1,1,1,1,0,0,1,1,1,0$ \\
& 6 & 74 & $1,2,0,0,0,0,0,0,1,1,0$ \\
\hline
\end{tabular}




\begin{tabular}{|c|c|c|c|}
\hline \multirow{7}{*}{7} & 1 & 612 & $2,2,0,0,0,0,0,0,0,1,0$ \\
\hline & 2 & 1006 & $2,2,1,0,0,0,0,0,0,0,0$ \\
\hline & 3 & 80 & $2,1,0,0,0,0,0,1,0,1,0$ \\
\hline & 4 & 380 & $1,2,0,0,0,0,0,0,0,0,0$ \\
\hline & 5 & 85 & $1,1,1,1,1,0,0,1,1,1,0$ \\
\hline & 6 & 74 & $1,2,0,0,0,0,0,0,1,1,0$ \\
\hline & 7 & 178 & $1,2,1,1,1,0,0,0,0,0,0$ \\
\hline \multirow{8}{*}{8} & 1 & 545 & $2,2,0,0,0,0,0,0,0,1,0$ \\
\hline & 2 & 996 & $2,2,1,0,0,0,0,0,0,0,0$ \\
\hline & 3 & 69 & $2,1,0,0,0,0,0,1,0,1,0$ \\
\hline & 4 & 380 & $1,2,0,0,0,0,0,0,0,0,0$ \\
\hline & 5 & 77 & $1,1,1,1,1,0,0,1,1,1,0$ \\
\hline & 6 & 71 & $1,2,0,0,0,0,0,0,1,1,0$ \\
\hline & 7 & 178 & $1,2,1,1,1,0,0,0,0,0,0$ \\
\hline & 8 & 99 & $2,2,1,0,0,0,0,1,1,1,0$ \\
\hline \multirow{9}{*}{9} & 1 & 516 & $2,2,0,0,0,0,0,0,0,1,0$ \\
\hline & 2 & 979 & $2,2,1,0,0,0,0,0,0,0,0$ \\
\hline & 3 & 67 & $2,1,0,0,0,0,0,1,0,1,0$ \\
\hline & 4 & 335 & $1,2,0,0,0,0,0,0,0,0,0$ \\
\hline & 5 & 76 & $1,1,1,1,1,0,0,1,1,1,0$ \\
\hline & 6 & 71 & $1,2,0,0,0,0,0,0,1,1,0$ \\
\hline & 7 & 175 & $1,2,1,1,1,0,0,0,0,0,0$ \\
\hline & 8 & 99 & $2,2,1,0,0,0,0,1,1,1,0$ \\
\hline & 9 & 97 & $1,1,0,0,0,1,0,0,0,0,0$ \\
\hline \multirow{10}{*}{10} & 1 & 359 & $1,2,0,0,0,0,0,0,0,1,0$ \\
\hline & 2 & 411 & $1,2,1,0,0,0,0,0,0,0,0$ \\
\hline & 3 & 314 & $2,2,0,0,0,0,0,1,0,1,0$ \\
\hline & 4 & 256 & $1,2,0,0,0,0,0,0,0,0,0$ \\
\hline & 5 & 75 & $1,1,1,1,1,0,0,1,1,1,0$ \\
\hline & 6 & 150 & $2,2,0,0,0,0,0,0,1,1,0$ \\
\hline & 7 & 103 & $1,2,1,1,1,0,0,0,0,0,0$ \\
\hline & 8 & 122 & $2,2,1,0,0,0,0,1,1,1,0$ \\
\hline & 9 & 67 & $1,1,0,0,0,1,0,0,0,0,0$ \\
\hline & 10 & 558 & $2,2,1,0,0,0,0,0,0,0,0$ \\
\hline
\end{tabular}

\section{Penentuan Jumlah Klaster Optimal}

Jumlah klaster yang optimal ditentukan menggunakan metode Davies-Bouldin Index (DBI). Semakin kecil nilai DBI akan memberikan hasil yang baik, berikut merupakan contoh penghitungan nilai DBI untuk $\mathrm{k}=2$.

1. Jarak antar centroid klaster

Jarak antara centroid klaster 1 dan 2

$$
\begin{aligned}
d\left(V_{1}, V_{2}\right)=\delta(1,2) & +\ddot{a}(2,2)+\delta(0,1)+\delta(0,0)+\delta(0,0) \\
+ & \delta(0,0)+\delta(0,0)+\delta(0,0)+\delta(0,0) \\
+ & \delta(0,0)+\delta(0,0) \\
=1+0+1+0+0 & +0+0+0+0+0+0 \\
= & 2
\end{aligned}
$$

2. Jarak masing-masing anggota klaster terhadap centroid masing-masing klaster (i). Jarak masing-masing anggota klaster 1 terhadap centroid klaster 1

$$
\begin{aligned}
d\left(T_{1}, V_{1}\right)= & \delta(1,1)+\delta(1,2)+\delta(0,0)+\delta(0,0)+\delta(1,0) \\
& \quad+\delta(0,0)+\delta(0,0)+\delta(0,0)+\delta(0,0) \\
& \quad+\delta(0,0)+\delta(0,0) \\
= & 0+1+0+0+1+0+0+0+0+0+0 \\
= & 2
\end{aligned}
$$

Dan seterusnya sampai anggota ke-1595

(ii). Jarak masing-masing anggota klaster 2 terhadap centroid klaster 2

$$
\begin{aligned}
d\left(T_{2}, V_{2}\right)=\delta(2,2) & +\delta(2,2)+\delta(1,1)+\delta(0,0)+\delta(0,0) \\
& +\delta(0,0)+\delta(0,0)+\delta(1,0)+\delta(1,0) \\
& +\delta(0,0)+\delta(0,0) \\
= & 0+1+0+0+1+0+0+0+0+0+0 \\
= & 2
\end{aligned}
$$

Dan seterusnya sampai anggota ke- 820

3. Ukuran dispersi masing-masing klaster

Ukuran dispersi klaster 1

$$
s_{1}=\left[\frac{1}{1595} \times\left(2^{2}+1^{2}+5^{2}+\cdots+4^{2}\right)\right]^{\frac{1}{2}}=2,4817
$$

Ukuran dispersi klaster 2

$$
s_{2}=\left[\frac{1}{820} \times\left(2^{2}+1^{2}+3^{2}+\cdots+3^{2}\right)\right]^{\frac{1}{2}}=1,6770
$$

4. Ukuran kemiripan antara klaster 1 dan 2

$$
R_{12}=\frac{s_{1}+s_{2}}{d\left(V_{1}, V_{2}\right)}=\frac{2,4817+1,6770}{2}=2,0794
$$

5. Matriks R (2x2)

$$
\boldsymbol{R}=\left[\begin{array}{cc}
- & 2,0794 \\
2,0794 & -
\end{array}\right]
$$

6. Nilai Davies-Bouldin Index

$$
\begin{gathered}
D B I=\frac{1}{2} \sum_{a=1}^{2} R_{a}=\frac{1}{2} \times(2,0794+2,0794) \\
=2,07944
\end{gathered}
$$

Langkah yang sama dilakukan untuk mencari DBI $\mathrm{k}=3,4, \ldots, 10$ sehingga diperoleh nilai DBI yang tertera pada tabel 3 .

\begin{tabular}{cc} 
Tabel 4.3 Nilai DBI k=2,3,,., 10 \\
\cline { 1 - 2 } $\mathbf{k}$ & $\mathbf{D B I}$ \\
\hline 2 & 2,0794 \\
3 & 1,7293 \\
4 & 1,8206 \\
5 & 1,6645 \\
6 & 1,6264 \\
7 & 1,5236 \\
8 & 1,4067 \\
\hline
\end{tabular}




\begin{tabular}{cc}
\hline 9 & 1,3427 \\
10 & 1,6398 \\
\hline
\end{tabular}

Pada Tabel 4.3 dapat dilihat bahwa DBI terkecil dimiliki oleh $\mathrm{k}=9$ yaitu sebesar 1,3427.
Sehingga dapat disimpulkan bahwa jumlah klaster optimal untuk mengelompokkan minat belanja online sebanyak 9 klaster.

\section{Interpretasi dan Profiling Hasil Klaster k=9}

Tabel 4.4 Karakteristik masing-masing klaster untuk k=9

\begin{tabular}{|c|c|c|c|c|c|c|c|c|c|c|c|c|}
\hline Klaster & JK & Umur & Shopee & Bukalapak & Tokopedia & Lazada & Lainnya & Ig & $\mathrm{Fb}$ & $\begin{array}{c}\text { Media } \\
\text { Chatting }\end{array}$ & Twitter & $\begin{array}{c}\text { Jumlah } \\
\text { Anggota }\end{array}$ \\
\hline 1 & Perempuan & Dewasa & Tidak & Tidak & Tidak & Tidak & Tidak & Tidak & Tidak & Ya & Tidak & 516 \\
\hline 2 & Perempuan & Dewasa & $\mathrm{Ya}$ & Tidak & Tidak & Tidak & Tidak & Tidak & Tidak & Tidak & Tidak & 979 \\
\hline 3 & Perempuan & Muda & Tidak & Tidak & Tidak & Tidak & Tidak & Ya & Tidak & Ya & Tidak & 67 \\
\hline 4 & Laki-laki & Dewasa & Tidak & Tidak & Tidak & Tidak & Tidak & Tidak & Tidak & Tidak & Tidak & 335 \\
\hline 5 & Laki-laki & Muda & Ya & Ya & Ya & Tidak & Tidak & Ya & Ya & Ya & Tidak & 76 \\
\hline 6 & Laki-laki & Dewasa & Tidak & Tidak & Tidak & Tidak & Tidak & Tidak & Ya & Ya & Tidak & 71 \\
\hline 7 & Laki-laki & Dewasa & Ya & Ya & Ya & Tidak & Tidak & Tidak & Tidak & Tidak & Tidak & 175 \\
\hline 8 & Perempuan & Dewasa & Ya & Tidak & Tidak & Tidak & Tidak & Ya & Ya & Ya & Tidak & 99 \\
\hline 9 & Laki-laki & Muda & Tidak & Tidak & Tidak & Ya & Tidak & Tidak & Tidak & Tidak & Tidak & 97 \\
\hline
\end{tabular}

Berdasarkan Tabel 4.4, berikut adalah penamaan dan karakteristik untuk masingmasing klaster

a. Klaster 1, cukup minat belanja melalui media sosial

Klaster 1 terdiri atas orang-orang yang cukup minat belanja melalui Media Sosial yaitu Media Chatting, kategori ini didominasi oleh perempuan umur dewasa (25-59 tahun)

b. Klaster 2, cukup minat belanja melalui Marketplace

Klaster 2 terdiri atas orang-orang yang cukup minat belanja melalui Marketplace yaitu Shopee, kategori ini didominasi oleh perempuan umur dewasa (25-59 tahun)

c. Klaster 3, minat belanja melalui Media Sosial

Klaster 3 terdiri atas orang-orang yang minat belanja melalui Media Sosial yaitu Instagram dan Media Chatting, kategori ini didominasi oleh perempuan umur muda (1524 tahun) d. Klaster 4, tidak minat belanja online Klaster 4 terdiri atas orang-orang yang tidak minat belanja melalui Marketplace maupun Media Sosial, kategori ini didominasi oleh laki-laki umur dewasa (25-59 tahun)

e. Klaster 5, sangat minat belanja melalui Marketplace dan Media Sosial

Klaster 5 terdiri atas orang-orang yang sangat minat belanja melalui Marketplace yaitu Shopee, Bukalapak, dan Tokopedia, serta Media Sosial yaitu Instagram, Facebook, dan Media Chatting, kategori ini didominasi oleh laki-laki umur muda (15-24 tahun)

f. Klaster 6, minat belanja melalui Media Sosial

Klaster 6 terdiri atas orang-orang yang minat belanja melalui Media Sosial yaitu Facebook dan Media Chatting, kategori ini didominasi oleh laki-laki umur dewasa (25-59 tahun)

g. Klaster 7, sangat minat belanja melalui Marketplace 
Klaster 7 terdiri atas orang-orang yang sangat minat belanja melalui Marketplace yaitu Shopee, Bukalapak, dan Tokopedia, kategori ini didominasi oleh laki-laki umur dewasa (25-59 tahun)

h. Klaster 8, cukup minat belanja melalui Marketplace dan sangat minat belanja melalui media sosial

Klaster 8 terdiri atas orang-orang yang cukup minat belanja melalui Marketplace yaitu Shopee, serta sangat minat belanja melalui Media Sosial yaitu Instagram, Facebook, dan Media Chatting, kategori ini didominasi oleh perempuan umur dewasa (25-59 tahun)

i. Klaster 9, cukup minat belanja melalui Marketplace

Klaster 9 terdiri atas orang-orang yang cukup minat belanja melalui Marketplace yaitu Lazada, kategori ini didominasi oleh laki-laki umur muda (15-24 tahun)

Sebagian besar masyarakat di DI Yogyakarta termasuk dalam kategori cukup minat belanja melalui Marketplace yaitu Shopee. Masyarakat yang tidak minat melakukan belanja online juga masih cukup banyak. Apabila kesembilan klaster dibandingkan, maka klaster yang terbaik adalah klaster 5 dimana merupakan klaster yang anggotanya sangat minat belanja melalui Marketplace dan Media Sosial. Marketplace yang diminati adalah Shopee, Bukalapak, dan Tokopedia, sedangkan Media Sosial yang diminati adalah Instagram, Facebook, dan Media Chatting. Kemudian lakilaki umur muda (15-24 tahun) yang mendominasi kategori ini. Sehingga bagi pengusaha yang ingin membuka online shop atau bahkan sudah memiliki online shop disarankan untuk menjual barang-barang laki-laki untuk umur muda dan memasarkannya melalui Shopee, Bukalapak, Tokopedia, Instagram, Facebook, atau Media Chatting sehingga lebih banyak memperoleh pembeli.

\section{KESIMPULAN}

Berdasarkan analisis deskriptif dapat disimpulkan bahwa penduduk Daerah Istimewa Yogyakarta baik laki-laki maupun perempuan memiliki kecenderungan yang sama dalam melakukan belanja secara online, dimana penduduk yang paling banyak melakukan belanja online berumur dewasa (25-59 tahun). Hal ini karena penduduk yang masuk dalam rentang umur ini biasanya sudah bekerja dan memiliki penghasilan. Platform yang sering digunakan untuk belanja online adalah Shopee sedangkan paling sedikit digunakan adalah Twitter.

Berdasarkan hasil DBI, jumlah klaster optimum untuk mengelompokkan minat belanja online penduduk Daerah Istimewa Yogyakarta adalah 9 klaster dimana klaster 5 merupakan klaster dengan kategori terbaik dengan yaitu sangat minat belanja melalui Marketplace dan Media Sosial. Marketplace yang diminati adalah Shopee, Bukalapak, dan Tokopedia, sedangkan Media Sosial yang diminati adalah Instagram, Facebook, dan Media Chatting. Klaster ini didominasi oleh laki-laki umur muda (15-24 tahun).

Berdasarkan hal tersebut disarankan bagi pengusaha yang ingin membuka online shop atau bahkan sudah memiliki online shop disarankan untuk menjual barang-barang laki-laki untuk umur muda dan memasarkannya melalui Shopee, Bukalapak, Tokopedia, Instagram, Facebook, atau Media Chatting sehingga lebih banyak memperoleh pembeli.

\section{DAFTAR PUSTAKA}

[1] Anita, Muharmi, Y., \& Siska, S. T. (2018). Penentuan Tingkat Minat Belanja Online Melalui Media Sosial Menggunakan Metode Clustering K-Means. Rang Teknik Journal Vol. 1 No. 2, 126-134.

[2] Badruttamam, A., Sudarno, \& Maruddani, D. A. I. (2020). Penerapan Analisis Klaster k-Modes dengan Validasi Davies Bouldin Index dalam Menentukan Karakteristik 
Kanal Youtube di Indonesia. Jurnal Gaussian Vol.9 No.3, 263-272.

[3] Buteikis, A. (2018) Practical Econometric and Data Science. Diakses pada 11 Januari 2021, dari

http://web.vu.lt/mif/a.buteikis/wpcontent/uploads/PE_Book/1-intro.html.

[4] Fox, J. \& Monette, G. (1992). Generalized Collinearity

Diagnostics. Journal of the American Statistical Association Vol. 87 No. 417, 178-83.

[5] Fraley, C. \& Raftery A. E. (1998). How Many Clusters? Which Clustering Method? Answers Via Model-Based Cluster Analysis. The Computer Journal Vol.41 No.8, 578-588.

[6] Gujarati, D. N. \& Porter, D. C. (2009). Basic Econometrics Fifth Edition. New York : McGraw-Hill.

[7] Hair, J. F., et al. (2014). Multivariate Data Analysis Seventh Edition. Harlow : Pearson.

[8] Hilmi, M. N., Wilandari, Y., \& Yasin, H. (2015). Pemetaan Preferensi Mahasiswa Baru dalam Memilih Jurusan Menggunakan Artificial Neural Network (ANN) dengan Aalgoritma Self Organizing Maps (SOM). Jurnal Gaussian Vol. 4 N. 1, 53-60.

[9] Huang, J. Z. (2009). Clustering Categorical Data with k-Modes. Encyclopedia of Data Warehousing and Mining.

[10] Huang, Z. (1997). A Fast Clustering Algorithm to Cluster very Large Categorical Data Sets in Data Mining. SIGMOD Workshop on Research Issues on Data Mining and Knowledge Discovery (DMKD'97).

[11] Johnson, R. A. \& Winchern, D. W. (2002). Applied Multivariate Statistical Analysis. New Jersey: Prentice Hall.

[12] Laudon, K. \& Traver, C. G. (2017). ECommerce 2016 : Business, Technology, Society. Harlow : Pearson Education.

[13] Mattjik, A.A. \& Sumertajaya, I.M. (2011). Sidik Peubah Ganda. Bogor : IPB Press.

[14] O’Driscoll, D. \& Ramirez, D. E. (2015). Response Surface Designs Using the
Generalized Variance Inflation Factors. Cogent Mathematics Vol. 2 No. 1.

[15] Permatadevi, M. A., Hendrawan, R. A., \& Hafidz, I. (2013). Karakteristik Pelanggan Telepon Kabel Menggunakan Clustering SOM dan K-Means untuk Mengurangi Kesalahan Klasifikasi Pelanggan Perusahaan Telekomunikasi. Jurnal Teknik Pomits Vol.1 No.1, 1-6.

[16] Ramdhani, F., Hoyyi, A., \& Mukid, M. A. (2015). Pengelompokkan Provinsi di Indonesia Berdasarkan Karakteristik Kesejahteraan Rakyat Menggunakan Metode K-Means Cluster. Jurnal Gaussian Vol.4 No.4, 875-884.

[17] Romzi, M., Anggorowati, M.A., Mariyah, S. Data Mining And Knowledge Management. Jakarta : Sekolah Tinggi Ilmu Statistik.

[18] Sukamto, Daqiqil, I., \& Angraini, T. R. (2018). Penentuan Daerah Rawan Titik Api di Provinsi Riau Menggunakan Clustering Algoritma K-Means. Jurnal Informatika Vol.6 No.2, 137-148.

[19] Supranto, J. (2004). Analisis Multivariat : Arti dan Interpretasi. Jakarta : Rineka Cipta.

[20] Tapscott, D. (2015). The Digital Economy Anniversary Edition: Rethinking Promise and Peril in the Age of Networked Intelligence. New York : McGraw-Hill Education.

[21] Turban, E., et al. (2015). Electronic Commerce : a Managerial and Social Networks Perspective Eighth Edition. Springer Text in Business and Economics.

[22] Van Ark, B., et al. (2016). Navigating the new digital economy: driving digital growth and productivity from installation to deployment.

[23] Yuliana, L. (2019). Penerapan Algoritma K-Modes Clustering untuk Pengelompokkan Desa Rawan Kebakaran di Provinsi Riau (Studi Kasus : BPBD Riau). Tugas Akhir. Pekanbaru : Fakultas Sains dan Teknologi, Universitas Islam Negeri Sultan Syarif Kasim Riau.

[24] Yulianita, T., \& Istiawan, D. (2017). Implementasi Algoritma K-Modes untuk 
Penerapan Algoritma K-Modes Clustering Dengan Validasi Davies Bouldin Index Pada Pengelompokkan

Penentuan Prioritas Rehabilitasi Daerah Aliran Sungai Berdasarkan Parameter Lahan Kritis. The $6^{\text {th }}$ University Research Colloquium $2017 \quad$ Universitas Muhammadiyah Magelang, 429-440 